\title{
The Construction of the COVID-19 Pandemic: Designing Societal Solutions That Would Prevent a Full Lockdown
}

\author{
A. Georges L. Romme \\ Department of Industrial Engineering \& Innovation Sciences \\ Eindhoven University of Technology \\ P.O. Box 513, 5600 MB Eindhoven, The Netherlands \\ E-mail: a.g.l.romme@tue.nl
}

Received: June 11, 2020 Accepted: June 30, 2020 Online published: July 15, 2020

doi:10.5296/jpag.v10i3.17356

URL: https://doi.org/10.5296/jpag.v10i3.17356

\begin{abstract}
The COVID-19 pandemic has triggered one of the deepest economic recessions in human history, largely as a result of the full lockdown strategy adopted by many national governments. This lockdown strategy was primarily motivated by the limited capacities of Intensive Care Units and a lack of medical staff and equipment. In this essay, I argue that the COVID crisis and the widely used lockdown response are socially constructed, which invites a public discourse on how we can design societal solutions that would prevent the need for an indiscriminate lockdown response to a future pandemic or any other similar crisis. One potential solution is further developed in this essay: the design of latent capabilities for responding to any future emergencies. These latent capabilities, embedded in many host organizations, can help in quickly resolve shortages in professional skills and resources, which are likely to occur in any future crisis. Here, the COVID-19 crisis provides a major learning opportunity, to be exploited as soon as possible.
\end{abstract}

Keywords: COVID-19, pandemic, lockdown, crisis, crisis prevention, latent organizing

\section{Introduction}

The current COVID-19 pandemic has triggered one of the deepest economic recessions in human history, largely as a result of the lockdown strategy adopted by many national governments. In the period March to May 2020, more than a third of the world population was placed in full lockdown (McFall-Johnsen et al., 2020), with severe economic and social consequences: many companies were pushed to the verge of bankruptcy, with millions of 
employees and freelance workers becoming unemployed and (often) losing their health insurance at the same time, with major long-term consequences in terms of hunger and life expectation (Saad-Filho, 2020). In this short essay, I argue that the COVID crisis and the widely used lockdown response are socially constructed (cf., Dolmans et al., 2014). Social constructionism essentially says that (the development of) jointly constructed understandings form the basis for shared assumptions about reality. In other words, our shared ideas and beliefs provide the backbone of the way we perceive, approach and handle reality. The constructionist nature of the crisis and the responses adopted also opens the door for a public discourse on how we can design societal solutions that would prevent the need for an indiscriminate lockdown response to a future pandemic or any other similar crisis.

In this respect, the COVID-19 pandemic appears to have originated in Wuhan (China), but its diffusion rate was (unintendedly) fueled by global supply chains, international tourism, large-scale events in various countries, and other phenomena we created ourselves. Moreover, the lockdown strategy adopted by many national governments was a deliberate choice, primarily informed by limited capacities of Intensive Care Units (ICUs) and a lack of medical staff and equipment - even in countries known for their excellent health care infrastructure. Prior to the pandemic, several decades of neo-liberalist governance had severely undermined the public health care system in the USA, UK, Netherlands and many other countries - in the name of the espoused 'efficiency' of the market (Saad-Filho, 2020). As a result, many countries suffered from a lack of protective gear for health professionals, diagnostic tests, medical equipment and ICU beds when the number of infected patients with severe symptoms started to grow exponentially (Wikipedia, 2020). In the past 10 to 15 years, experts repeatedly warned for the high risks arising from a potential pandemic (e.g., Van der Giessen et al., 2010), but political leaders again and again decided to ignore these signals.

Notably, the political choice for a lockdown response to COVID-19 has raised some public debate, but most critical voices have been suppressed, ignored, bullied or put aside as conspiracy theorists [e.g., Boudry, 2020; Gomez \& Ramcharan, 2020). Even at the time this essay was written (early June 2020), there is hardly any public debate about the pros and cons of the indiscriminate lockdown strategy adopted by many national governments. Prominent scholars like Michael Levitt (2020) have criticized this full lockdown strategy and advocated a smart response approach instead, focused on physical distancing, masks and hand sanitizers.

\section{What can We Learn From This Crisis?}

In any case, a public discourse on the short-term and long-term consequences of the various response strategies adopted to handle COVID-19 is highly needed. And this discourse must address the moral, social and economic aspects and implications of the full lockdown approach as well as its alternatives. More specifically, this public discourse needs to acknowledge the complexity of societal responses to a COVID-like crisis and consider more targeted measures at local and organizational levels (Espejo, 2020).

A key question here is what we can learn from the COVID-19 pandemic regarding medical and other capabilities required to handle any future crisis. As observed earlier, a pivotal factor 
in the COVID-19 crisis is the enormous shortage of ICU beds, equipment and medical staff, which was the primary driver of many national governments trying to curb the spread of the virus by a full lockdown. In the more affluent regions of the world, the sheer lack of ICU beds and equipment is relatively easy to address; for example, the European Commission recently decided to create a strategic stockpile of medical equipment such as ventilators and protective masks (European Commission, 2020). Supranational bodies like the United Nations and the WHO would need to help build a similar stockpile at other continents, like Africa.

The substantial shortages of medical doctors, nurses and other support staff in and around ICUs are much more challenging (Cheney, 2020). In the Netherlands, medical staff from the National Reserve Corps were brought in to help in and around several ICUs, and units of the Dutch army were assigned to coordinate and facilitate the transport of COVID-infected patients between hospitals. This raises the question as to how hospitals and national governments can better prepare themselves for any future crisis - whether it is a new virus pandemic, a major earthquake, or a massive migration of people from one continent to another. In another paper, we called for the development of latent capabilities in preparing and responding to major catastrophes and emergency situations (Van Fenema \& Romme, 2020). For example, emergency response teams composed of trained people employed by other organizations can quickly respond to disasters such as major train crashes or floods. Another example is the voluntary fire brigade, composed of people employed by other organizations. An example in the COVID pandemic is the drastic transformation that many hotels had to make in their services and facilities, when they were accommodating guests with symptoms of the virus who got stuck in these hotels; some hotels even adjusted their operation to a hospital-like overflow care setting for patients. This example also suggests that not only hospitals suffered from the shortage of medical professionals, but a similar shortfall also occurred in many other sites.

A latent capability can be formally defined as resources and skills that remain dormant in the context of the regular activity domain of host organizations, until they are activated by an emergency or crisis situation that cannot be addressed within the given activity domain of the host organizations (Van Fenema \& Romme, 2020). Thus, the following questions arise from the corona crisis:

- How we can systematically design more latent capabilities for responding to major crises in companies, other (e.g., not-for-profit) organizations and local communities?

- What kind of mix of first-aid, medical, logistic or other capabilities should be trained? And what proportion of the population needs to be engaged, via various host organizations, in developing these capabilities?

- Can existing reservoirs of professionals (e.g., members of emergency response teams) be used and redesigned for this purpose, or are newly created networks of people more instrumental in building latent capabilities?

- What are the incentives and facilities provided by host organizations employing professionals that are key to a given latent (e.g., medical) capability for responding to 
crises? Should host organizations adapt employment contracts? Who pays the salary of professionals that work for several months outside their host organizations?

These and related questions can inform the policy development agenda for local, national and supranational governments.

\section{Conclusion}

Our society is socially constructed. Accordingly, any crisis is the result of human beings collectively creating and adapting social, economic and institutional artifacts, which interact with the biological and ecological conditions of planet earth. The COVID-19 pandemic and any future societal crisis is thus largely human-made. This perspective on pandemics and other crises also has a positive side: it creates ample opportunities for designing and sustaining latent capabilities for responding to any future emergencies. These latent capabilities can help in quickly resolve shortages in professional skills and resources, which are likely to occur in any crisis (Romme, 2016). Here, the corona-crisis provides a major learning opportunity, to be exploited as soon as possible.

\section{References}

Boudry, M. (2020). A strange paradox: The better we manage to contain the coronavirus, the less we will learn from it. The Conversation, April 3, 2020. Retrieved from: $\mathrm{https}$ ///theconversation.com/a-strange-paradox-the-better-we-manage-to-contain-the-coronavi rus-pandemic-the-less-we-will-learn-from-it-135268

Cheney, C. (2020). How to address intensivist shortfall during coronavirus pandemic. Retrieved from: https://www.healthleadersmedia.com

Dolmans, S.A.M., Van Burg, E., Reymen, I.M.M.J., \& Romme, A.G.L. (2014). Dynamics of resource slack and constraints: Resource positions in action. Organization Studies, 35, 511-549. https://doi.org/10.1177/0170840613517598

Espejo, R. (2020). COVID-19. Systems Research \& Behavioral Science, forthcoming. https://doi.org/10.1002/sres.2692

European Commission (2020). COVID-19: Commission creates first ever rescEU stockpile of medical equipment (press release, March 19, 2020). Retrieved from: https://ec.europa.eu/commission/presscorner/detail/en/IP_20_476

Gomez, J., \& Ramcharan, R. (2020). Covid crisis stifles political criticism in SE Asia. Bangkok Post, May 27, 2020. Retrieved from: https://www.bangkokpost.com

Levitt, M. (2020). Nobel prize winning scientist Prof Michael Levitt: Lockdown is a huge mistake. YouTube video: https://www.youtube.com/watch?v=bl-sZdfLcEk

McFall-Johnsen, M., Kaplan, J., \& Frias, L. (2020). A third of the global population is on coronavirus lockdown - here's our constantly updated list of countries and restrictions.. Business Insider Australia. Retrieved from: https://www.businessinsider.com.au/

Romme, G. (2016). The quest for professionalism: The case of management and 


\section{Macrothink}

Journal of Public Administration and Governance ISSN 2161-7104 2020, Vol. 10, No. 3

entrepreneurship. Oxford, United Kingdom: Oxford University Press. https://doi.org/10.1093/acprof:oso/9780198737735.001.0001

Saad-Filho, A. (2020). From COVID-19 to the end of neoliberalism. Critical Sociology, forthcoming. https://doi.org/10.1177/0896920520929966

Van der Giessen, J. W. B., Van de Giessen, A. W., \& Braks, M. A. H. (2010). Emerging zoonoses: Early warning and surveillance in the Netherlands. Bilthoven, Netherlands: RIVM. Retrieved from: https://www.rivm.nl/bibliotheek/rapporten/330214002.pdf

Van Fenema, P. C., \& Romme, A. G. L. (2020). Latent organizing for responding to emergencies: Foundations for research. Journal of Organization Design, 9, 11. https://doi.org/10.1186/s41469-020-00074-z

Wikipedia (2020). List of overwhelmed health care systems in the COVID-19 pandemic. Retrieved from: https://en.wikipedia.org/wiki/List_of_overwhelmed_health_care_systems_in_the_COVID-19 _pandemic

\section{Copyright Disclaimer}

Copyright for this article is retained by the author(s), with first publication rights granted to the journal.

This is an open-access article distributed under the terms and conditions of the Creative Commons Attribution license (http://creativecommons.org/licenses/by/4.0/). 